\title{
Spawning, fecundity, hatch-date frequency and young-of-the-year growth of bay anchovy Anchoa mitchilli in mid-Chesapeake Bay
}

\author{
C. E. Zastrow, E. D. Houde, L. G. Morin \\ Chesapeake Biological Laboratory, Center for Environmental and Estuarine Studies, The University of Maryland System, \\ PO Box 38, Solomons, Maryland 20688, USA
}

\begin{abstract}
Adult reproductive characteristics, hatch-date frequencies of new recruits, and young-ofthe-year growth from daily increments in otoliths of bay anchovy Anchoa mitchilli are reported from mid-Chesapeake Bay trawl collections in 1986 and 1987 . Males and females matured at 40 to $45 \mathrm{~mm}$ fork length at ca 10 mo posthatch. The spawning season extended from approximately mid-May to midAugust and peaked in July each year. Bay anchovy spawns in the evening, and virtually all females spawned nightly for ca 50 nights during the peak period. Daily batch fecundities were directly related to female size and ranged from 514 to 2026 ova. Mean relative fecundities did not differ between years $\left(\right.$ mean $=687$ ova $\left.^{-1}\right)$. Age-1 females produced 99.6 and $92.8 \%$ of the eggs spawned in July of 1986 and 1987, respectively. Females in the 50 to $55 \mathrm{~mm}$ length range contributed 53 and $57 \%$ of the eggs spawned in 1986 and 1987. No young-of-the-year anchovy, 35 to $42 \mathrm{~mm}$ fork length, that were examined were mature. Most recruited young-of-the-year anchovy collected in September and October were hatched in July. Peak hatching occurred in early July 1987 but occurred from mid- to late July in 1986. The earlier 1987 hatch dates may have resulted from earlier spawning in response to higher water temperatures. Mean growth rate of otolith-aged individuals 17.5 to $49.5 \mathrm{~mm}$ long was $0.47 \mathrm{~mm} \mathrm{~d}^{-1}$ in both 1986 and 1987
\end{abstract}

\section{INTRODUCTION}

The bay anchovy Anchoa mitchilli is believed to be the most abundant fish in the Chesapeake Bay, USA (Hildebrand \& Schroeder 1928), and is an important component of food webs and prey of piscivorous fishes (Baird \& Ulanowicz 1989). In the lower Chesapeake Bay, bay anchovy eggs and larvae dominate the ichthyoplankton from May until September (Olney 1983). In the mid-Chesapeake Bay, Dalton (1987) reported that spawning occurred from May to September and that the bay anchovy comprised $99 \%$ of all fish eggs and $67 \%$ of all fish larvae. Luo \& Musick (in press) recently described reproductive characteristics of bay anchovy collected in 1988 from the York River near the mouth of the Chesapeake Bay.

The reproductive season of bay anchovy may extend throughout the year in southern parts of its range (Houde \& Lovdal 1984), but the season is shorter at higher latitudes. Spawning near Beaufort, North Carolina, extends from late April to early September, with a peak in July (Kuntz 1914). In Barnegat Bay, New Jersey, and Great South Bay, New York, the spawning seasons may begin as early as April, peak in June and July and are essentially completed in August (Vouglitois et al. 1987, Monteleone 1988).

The annual abundance of bay anchovy in the Chesapeake Bay, estimated from trawl and seine surveys, apparently varies significantly (Horwitz 1987, Newberger \& Houde unpubl.). Variable levels of recruitment probably cause the annual fluctuations in abundance of this short-lived species. In this study, bay anchovy reproductive biology and recruitment, defined as the relative abundance (catch per unit effort) of young-of-the-year fish represented in trawl catches, were examined in 1986 and 1987 in mid-Chesapeake Bay. Our objectives were to determine: (1) size and age at first maturity; (2) seasonal maturation cycle; (3) time and frequency of spawning; (4) fecundity and its relationship to size; (5) hatch-date frequencies of recruited young-of-the-year anchovy; (6) growth rates of youngof-the-year anchovy. 


\section{METHODS}

Collections. Bay anchovy were collected in a $4.9 \mathrm{~m}$ semi-balloon trawl with a $3 \mathrm{~mm}$ mesh codend on a transect off the mouth of the Patuxent River in midChesapeake Bay. Collections in 1986 were made in March and in each month from May through November. In 1987, anchovies were trawled in February and in each month from April through November. Collections generally were made on a weekly basis during the summer months in both years. Fish were fixed in $10 \%$ buffered formalin (3.7\% formaldehyde) and transferred to $70 \%$ ethanol within $72 \mathrm{~h}$. Gonads from random subsamples of 10 to 20 males and 12 to 20 females of $\geq 40 \mathrm{~mm}$ fork length were removed and stored in $70 \%$ ethanol on at least a monthly basis and more frequently when samples were available. Each anchovy was measured to the nearest $1.0 \mathrm{~mm}$ fork length and weighed to the nearest $1.0 \mathrm{mg}$ after blotting. Fish used for hatch-date and growth rate analyses were measured to the nearest $1.0 \mathrm{~mm}$ standard length.

Gonosomatic indices and oocyte measurements. To define the spawning season, gonosomatic indices (GSI) were determined by weighing each anchovy and its gonad to the nearest 1.0 and $0.1 \mathrm{mg}$, respectively, after blotting. GSI, expressed as a percent, was calculated as:

$$
\text { GSI }=100[\text { gonad weight/(anchovy weight }- \text { gonad }
$$

In addition to the monthly subsamples, GSI was determined from additional anchovies in the 35 to $42 \mathrm{~mm}$ fork length range from June through September to estimate length at first maturity and to determine if the smallest age- 1 anchovy (10 to 14 mo old fish collected in June) were mature and to determine if the largest age-0+ anchovy (young-of-the-year) spawn at ca 3 mo posthatch in August and September.

Oocyte measurements from preserved ovaries of 18 females were made on samples collected in July, August and November 1986 and in April 1987 to define the seasonal maturation cycle. Ovaries from 4 females on each sample date were excised and diameters of 100 randomly selected oocytes were measured with an ocular micrometer under a dissecting microscope. The near-spherical oocytes were measured along whichever axis fell along the micrometer scale. To determine if oocyte sizes differed among locations in the ovary, 2 females collected on 16 July 1986 were examined. One hundred oocytes from each of 4 sections in their ovaries - anterior left, posterior left, anterior right and posterior right - were measured, and results compared using Analysis of Variance (ANOVA).

Spawning periodicity and batch fecundity. Spawning periodicity and batch fecundities of females were estimated from trawl collections made repeatedly over a $29 \mathrm{~h}$ period on 29 and 30 July 1986 and over a $24 \mathrm{~h}$ period on 30 June and 1 July 1987 . These collections provided 12 anchovy samples that included ovaries from 408 females in 1986 and 11 anchovy samples that included ovaries from 173 females in 1987. Females were measured and weighed, and their excised ovaries stored in $10 \%$ formalin. An additional 84 ovary samples from other collection dates during the spawning season also were examined. Batch fecundity, defined as the numer of ova released per spawning, was determined by counting hydrated ova, which are in the final stage of maturation, having rapidly accumulated ovarian fluid just prior to being spawned (Hunter et al. 1985). The percentage of females in a sample that was about to spawn was determined from the ratio of females with hydrated ova to the total number of females in a sample (Hunter \& Macewicz 1985).

Hydrated ova from 10 randomly selected females in each year were counted to determine batch fecundities. Ovaries containing hydrated ova had been placed in Gilson's fluid (Bagenal 1978) at least $24 \mathrm{~h}$ prior to examination to break apart ovarian connective tissue and facilitate counting. All hydrated ova in the ovaries were counted to obtain the batch fecundity. Relative batch fecundity was calculated as the number of ova per $g$ of ovary-free female weight. Regression relationships between batch fecundity and female weight, ovary-free female weight, fork length and ovary weight were determined.

Relative egg production. Relative egg production by individual size and age-classes of females during the peaks of the spawning seasons was estimated. Lengthfrequency distributions and size-at-age data of adult bay anchovy from July collections in 1986 and 1987 (Newberger \& Houde unpubl.), combined with the length-specific fecundity data reported here, were used to estimate the percent egg production by lengthclasses and age-groups in each year.

Otolith preparation and analysis. Sagittal otoliths were removed from 227 young-of-the-year bay anchovy from August to October trawl collections (Table 1). Otoliths were mounted lateral surface up on microscope slides in Polybed 812 epoxy resin. The otoliths were ground in the sagittal plane with 400 and 600 grit wet/dry silicon carbide paper and subsequently polished with $0.3 \mu \mathrm{m}$ alumina paste.

Daily growth increments (a light incremental zone followed by a dark discontinuous zone) were counted from a $1000 \times$ image on a video-monitored image processing system. A subsample of 30 randomly-selected otoliths was read independently by 2 readers to check the accuracy and precision of increment counts made by the primary otolith reader.

Otolith increments are deposited daily in larval bay 
Table 1. Anchoa mitchilli. Young-of-the-year bay anchovy from mid-Chesapeake Bay examined to estimate growth rates and hatch dates

\begin{tabular}{|c|c|c|c|c|c|c|c|}
\hline \multirow[t]{2}{*}{ Date } & \multicolumn{4}{|c|}{ Standard length (mm) } & \multicolumn{3}{|c|}{ Growth rate $\left(\mathrm{mm} \mathrm{d}^{-1}\right)$} \\
\hline & $\mathrm{N}$ & $\overline{\mathrm{X}}$ & $\mathrm{SD}$ & Range & $\overline{\mathrm{X}}$ & $\mathrm{SD}$ & Range \\
\hline \multicolumn{8}{|l|}{1986} \\
\hline (combined) & 124 & 31.7 & 7.44 & $17.5-48.0$ & 0.47 & 0.04 & $0.36-0.61$ \\
\hline 29 Aug & 17 & 25.3 & 6.24 & $17.5-42.0$ & 0.45 & 0.04 & $0.36-0.51$ \\
\hline $10 \mathrm{Sep}$ & 64 & 29.0 & 6.05 & $20.0-47.0$ & 0.48 & 0.04 & $0.38-0.61$ \\
\hline $8 \mathrm{Oct}$ & 43 & 38.2 & 4.54 & $29.5-48.0$ & 0.47 & 0.03 & $0.42-0.54$ \\
\hline \multicolumn{8}{|l|}{1987} \\
\hline (combined) & 103 & 38.8 & 4.53 & $28.0-49.5$ & 0.47 & 0.04 & $0.41-0.58$ \\
\hline 11 Sep & 62 & 37.3 & 3.97 & $28.0-47.5$ & 0.48 & 0.03 & $0.41-0.58$ \\
\hline 6 Oct & 41 & 41.0 & 4.38 & $30.0-49.5$ & 0.45 & 0.03 & $0.41-0.57$ \\
\hline
\end{tabular}

anchovy (Fives et al. 1986, Leak \& Houde 1987). The first otolith increment was deposited at 2 to $3 \mathrm{~d}$ posthatch in the temperature range 23 to $29^{\circ} \mathrm{C}$ (Leak \& Houde 1987, Houde unpubl.). Therefore, age in days of trawl-collected young-of-the-year anchovy was estimated as number of otolith increments plus 2 .

Hatch-date determination. Hatch dates were determined from the daily increment counts in anchovy otoliths collected in September and October (Table 1). The analysis was restricted to this time period to help meet the assumption that all fish in the size range 20 to $50 \mathrm{~mm}$ SL would be equally vulnerable to capture by the trawl. Hatch-date frequency distributions were generated for the 1986 and 1987 year-classes. The hatch-date frequencies were aggregated into weekly cohorts to determine modal hatch dates of juvenile survivors.
Growth rate estimation. Individual growth rates in 1986 and 1987 were calculated as:

$$
G=\Delta \mathrm{SL} \div \text { (otolith increments }+2 \text { ) }
$$

where $G=$ growth rate $\left(\mathrm{mm} \mathrm{d}^{-1}\right) ; \Delta \mathrm{SL}=$ length at capture minus $2.0 \mathrm{~mm}$, the length at hatch; and otolith increments $+2=$ the estimated age of the individual.

\section{RESULTS}

\section{Length at maturation and spawning season}

Male and female bay anchovy matured at 40 to $45 \mathrm{~mm}$ fork length (Fig. 1), when GSI values were $\geq 3.0 \%$ for fish collected during the spawning season. The monthly mean GSI determined from samples of 10
Fig. 1. Anchoa mitchilli. Gonosomatic index in relation to fork length for female (with unhydrated ova) and male bay anchovy from mid-Chesapeake Bay, June-July, 1986 and 1987

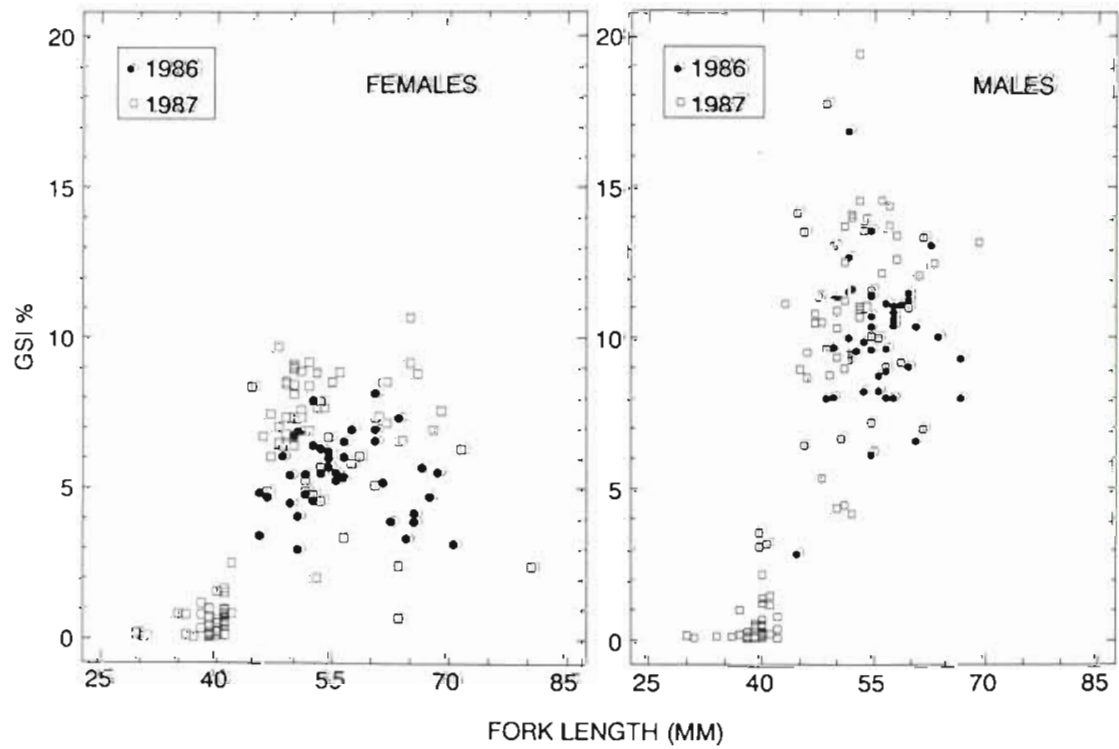




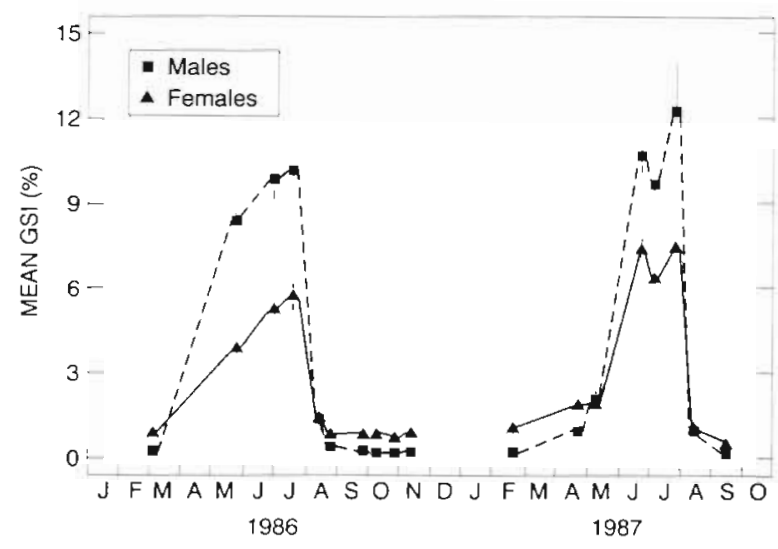

Fig. 2. Anchoa mitchilli. Mean gonosomatic index in relation to month of collection for male and female bay anchovy $\geq 40 \mathrm{~mm}$ FL from mid-Chesapeake Bay in 1986 and 1987

to 40 adult anchovy $>40 \mathrm{~mm}$ FL ranged from 0.47 to $7.40 \%$ for 416 unhydrated females and from 0.13 to $10.95 \%$ for 417 males. The mean GSI of mature ( $\geq 43 \mathrm{~mm}$ ) bay anchovy during the spawning season were $7.18 \%$ for males and $4.44 \%$ for females. The mean GSI of males and females from May to August did not differ significantly between years (Mann-Whitney test, $p>0.30$ ). However, the mean GSI for mature males was significantly higher than that of mature females in both years (Mann-Whitney test, $\mathrm{p}<0.0008$ ).

The mean GSI of 10 females in 1986 and 1987 that had hydrated ova and which were about to spawn did not differ significantly between years (Mann-Whitney test, $p>0.97)$. The pooled mean GSI of the 20 hydrated females was $16.83 \%(\mathrm{SE}=1.23 \%)$, a value significantly higher than the mean GSI of $6.43 \%$ of 100 unhydrated females during the peak spawning period (Mann-Whitney test, $p<0.0001$ ).
Based on GSI of males and unhydrated females $\geq 40 \mathrm{~mm}$, the 1986 and 1987 spawning seasons in midChesapeake Bay apparently extended from mid-May to mid-August (Fig. 2). GSI was low in March, increased in April and May, and peaked in July, before decreasing rapidly in August toward its lowest levels in fall and winter.

In June-July 1987, bay anchovy ranging in length from 35 to $42 \mathrm{~mm}$ fork length were small 10 to $14 \mathrm{mo}$ old individuals (Newberger 1989) (Table 2). Anchovy of similar lengths, but collected in August-September 1986 and 1987 , were large young-of-the-year individuals. The low mean GSI values $(\leq 0.21 \%$ ) of the 78 young-of-the-year anchovy that were examined indicated that they were immature and would not have spawned until the following year. The mean GSI of the 78 anchovy (10 to $14 \mathrm{mo}$ old, 35 to $42 \mathrm{~mm}$ ) was slightly higher $(\leq 1.13 \%)$ than that of the young-of-the-year anchovy (Table 2) but still much lower than the GSI of mature individuals. Although not certain, it is probable that the 35 to $42 \mathrm{~mm}, 10$ to 14 mo old anchovy did not spawn during 1987.

\section{Oocyte sizes}

There was no significant difference in mean oocyte diameter among 4 locations in the ovaries for 2 females (54 and $65 \mathrm{~mm}$ ) from a 16 July 1986 collection (ANOVA; $p=0.39$ and $p=0.79$ ). Therefore, the section of an ovary from which mean oocyte diameters were obtained for 16 additional females was selected at random.

Mean oocyte diameters were smallest in November $(0.11$ to $0.12 \mathrm{~mm})$, increased slightly in April $(0.13$ to

Table 2. Anchoa mitchilli. Mean gonosomatic indices of bay anchovy 35 to $42 \mathrm{~mm}$ fork length from June to September in 1986 and 1987. Age 0+ designates young-of-the-year anchovy $<3.5$ mo posthatch. Age 1 designates anchovy of actual age 10 to 14 mo posthatch

\begin{tabular}{|c|c|c|c|c|}
\hline Date & $N$ & Age & $\bar{X} F L$ & GSI $(\%)$ \\
\hline \multicolumn{5}{|l|}{ Females } \\
\hline 21 Aug 86 & 9 & $0+$ & $40.7(0.8)$ & $0.15(.02)$ \\
\hline 10 Sep 86 & 10 & $0+$ & $41.2(0.9)$ & $0.21 \quad(.04)$ \\
\hline 3 Jun 87 & 11 & 1 & $39.3(0.6)$ & $1.13(.14)$ \\
\hline $15 \& 28$ Jul 87 & 26 & 1 & $38.6(0.6)$ & $0.37(.06)$ \\
\hline 12 Aug 87 & 10 & $0+$ & $39.2(0.8)$ & $0.16(.04)$ \\
\hline 11 Sep 87 & 10 & $0+$ & $39.7(0.9)$ & $0.19(.03)$ \\
\hline \multicolumn{5}{|l|}{ Males } \\
\hline 21 Aug 86 & 9 & $0+$ & $40.1(0.9)$ & $0.04 \quad(0.01)$ \\
\hline 10 Sep 86 & 10 & $0+$ & $41.1\{0.9\}$ & $0.04(0.01)$ \\
\hline 3 Jun 87 & 13 & 1 & $39.1(0.6)$ & $1.04(0.37)$ \\
\hline $15 \& 28$ Jul 87 & 28 & 1 & $38.9(0.6)$ & $0.51 \quad(0.15)$ \\
\hline 12 Aug 87 & 10 & $0+$ & $38.3(0.9)$ & $0.04(0.01)$ \\
\hline 11 Sep 87 & 10 & $0+$ & $40.1 \quad(0.6)$ & $0.04(0.01)$ \\
\hline
\end{tabular}


Fig. 3. Anchoa mitchilli. Pooled size-frequency distributions of 100 ova from each of 4 female bay anchovy from 4 collection dates $(N=4$ females and $N=400$ ova for each distribution)

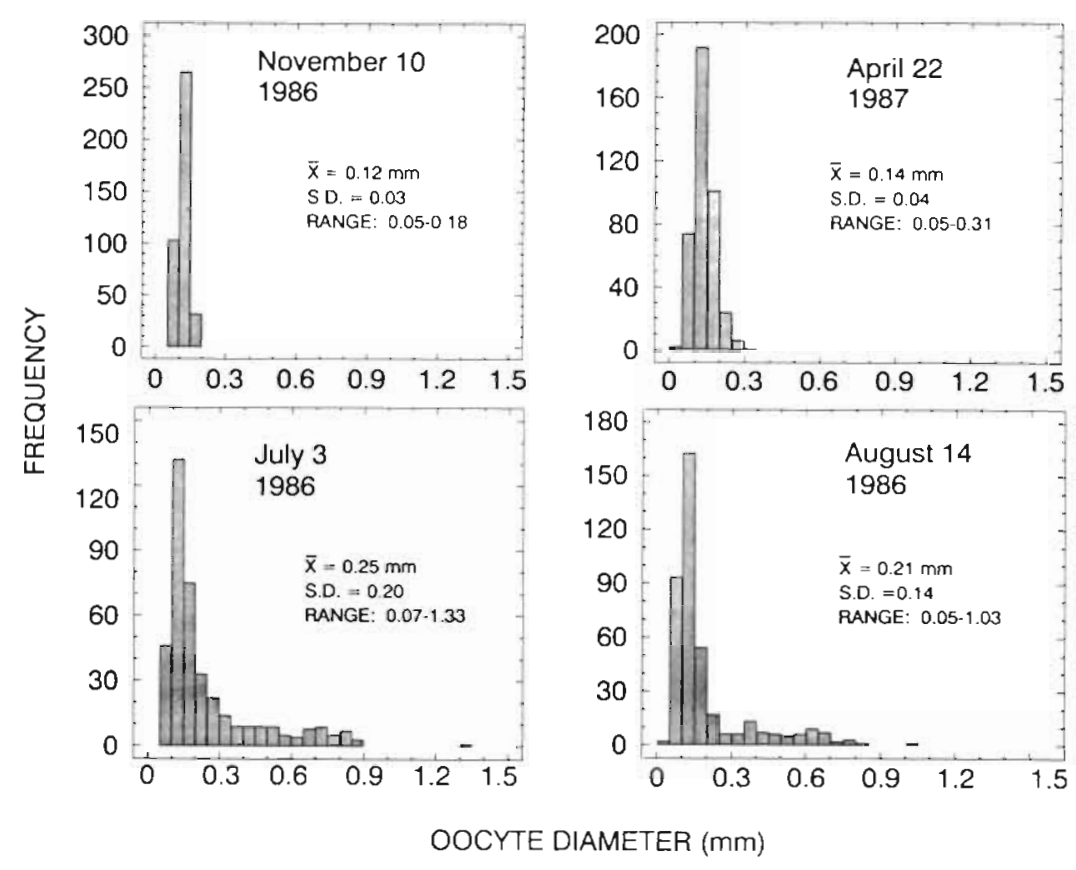

$0.15 \mathrm{~mm})$, reached a maximum in July $(0.21$ to $0.28 \mathrm{~mm}$ ), and decreased in August (0.12 to $0.23 \mathrm{~mm}$ ). Vitellogenic oocytes $>0.20 \mathrm{~mm}$ diameter were not present in November, appeared in April ( $\bar{x}=0.23 \mathrm{~mm})$ and reached maximum mean diameter by July and August $(\overline{\mathrm{x}}=0.44$ to $0.45 \mathrm{~mm}$, respectively) (Fig. 3 ).

The ova size-frequency distributions differed significantly on the 4 sampling dates (Fig. 3). The November and April distributions were not significantly different (Kolmogorov-Smimov test, $\mathrm{p}>0.001$ ). The November sample had only small $(<0.20 \mathrm{~mm})$ primary oocytes, but in April a few larger vitellogenic oocytes were present. The November and April distributions did differ significantly from those in July and August (Kolmogorov-Sminov test, $\mathrm{p}<0.001$ ). At least 2 modes of vitellogenic oocytes, at ca 0.4 and $0.7 \mathrm{~mm}$ diameter, were present in the July and August samples. When all oocyte size-classes were considered, the July and August distributions were significantly different (Kolmogorov-Smirnov test, $\mathrm{p}<0.001$ ), primarily because of the higher percentage of pre-vitellogenic oocytes $(<0.1 \mathrm{~mm})$ in August. When only the vitellogenic oocytes $(>0.2 \mathrm{~mm}$ ) were considered, there was no significant difference in July and August distributions (Kolmogorov-Smirnov test, $\mathrm{p}>0.001$ ).

\section{Time of spawning and spawning frequency}

Hydrated ova first appeared in evening samples, beginning at about 18:00 h. Hydration occurred between 17:00 and 18:00 h and most females had fully hydrated ova by $18: 00$ h (Table 3 ). Most spawning probably occurred between 21:00 and 24:00 h. Sixtyfour females collected between 24:00 and 01:00 h during the peak of the spawning season included only fish with partially and fully spent ovaries. No hydrated ova were observed after $00: 33 \mathrm{~h}$, indicating that daily spawning activity was completed by that time (Table 3). In June and July, 67 to $100 \%$ of the females collected between 17:57 and 23:00 h had hydrated ova. On 10 June 1987, between 18:07 and 18:42, 9 of 11 females $(81.8 \%)$ had hydrated ova (Table 3$)$. On later June dates and on all July 1987 dates, every female collected between 17:57 and 23:00 h had hydrated ova, indicating that virtually all mature bay anchovy females spawned each night during the peak of the 1987 spawning season.

A single sample of 17 females collected at 18:30 h on 21 August 1986 had no females with hydrated ova (Table 3), suggesting that the spawning season was essentially over by that date. All but one of those 17 females had only primary, pre-vitellogenic oocytes in their ovaries. The exceptional female had some vitellogenic oocytes ranging from 0.28 to $0.40 \mathrm{~mm}$, but its ovaries were small and flaccid, and its GSI was low $(0.36 \%)$.

\section{Fecundity}

Daily batch fecundities, which correspond to numbers of hydrated ova, from 10 females examined each year, ranged from 618 to 1478 on 30 July 1986, and from 514 to 2026 on 30 June 1987. Relative batch fecundity, defined as number of hydrated ova per gram of ovary-free female weight, ranged from 441.8 to 918.7 
Table 3. Anchoa mitchilli. Percentage of female bay anchovy with hydrated ova in mid-Chesapeake Bay during 1986 and 1987. Data are from $24 \mathrm{~h}$ and $29 \mathrm{~h}$ time series, plus additional late afternoon/early evening samples (")

\begin{tabular}{|c|c|c|c|c|}
\hline Date & Collection time $(\mathrm{h})$ & No examined & Fork lengths (mm) & $\begin{array}{c}\% \text { Females in hydrated } \\
\text { condition }\end{array}$ \\
\hline 29 Jul 86 & $\begin{array}{c}10: 35-17: 50 \\
\text { (5 samples) }\end{array}$ & 187 & $47-75$ & 0 \\
\hline 30 Jul 86 & $00: 01$ & 50 & $45-69$ & 94.0 \\
\hline 30 Jul 86 & $00: 33$ & 14 & $47-63$ & 14.3 \\
\hline 30 Jul 86 & $\begin{array}{c}01: 00-14: 51 \\
(5 \text { samples })\end{array}$ & 140 & $46-72$ & 0 \\
\hline - 21 Aug 86 & $18: 30$ & 17 & $46-56$ & 0 \\
\hline - 10 Jun 87 & $18: 07$ & 5 & $50-53$ & 80.0 \\
\hline - 10 Jun 87 & $18: 24$ & 3 & $51-70$ & 67.0 \\
\hline - 10 Jun 87 & $18: 42$ & 3 & $46-52$ & 100 \\
\hline - 16 Jun 87 & $17: 34$ & 9 & $50-65$ & $0^{\mathrm{a}}$ \\
\hline - 16 Jun 87 & $17: 57$ & 7 & $45-54$ & 100.0 \\
\hline - 16 Jun 87 & $18: 15$ & 10 & $44-62$ & 100.0 \\
\hline - 24 Jun 87 & $18: 03$ & 4 & $48-69$ & 100.0 \\
\hline - 24 Jun 87 & $18: 21$ & 1 & 62 & 100.0 \\
\hline 30 Jun 87 & $\begin{array}{c}10: 05-14: 45 \\
(5 \text { samples) }\end{array}$ & 52 & $47-79$ & 0 \\
\hline \multirow[t]{2}{*}{30 Jun 87} & $20: 52$ & 14 & $44-69$ & 100.0 \\
\hline & $21: 03$ & 63 & $45-69$ & 100.0 \\
\hline $1 \mathrm{Jul} 87$ & $\begin{array}{c}03: 23-09: 20 \\
\text { (4 samples) }\end{array}$ & 44 & $46-74$ & 0 \\
\hline • $22 \mathrm{JuJ} 87$ & $\begin{array}{c}17: 17-17: 45 \\
\text { (2 samples) }\end{array}$ & 22 & $48-60$ & $0^{\mathrm{a}}$ \\
\hline - 28 Jul 87 & $16: 11$ & 2 & $63-67$ & 0 \\
\hline - 28 Jul 87 & $23: 00$ & 1 & 83 & 100 \\
\hline
\end{tabular}

in 1986 and from 467.3 to 959.2 in 1987. Mean relative batch fecundity was 642.9 ova $^{-1}$ in 1986 ( $\mathrm{SE}=45.9$ ) and 731.2 ova $\mathrm{g}^{-1}$ in 1987 ( $\left.\mathrm{SE}=64.8\right)$. The mean relative fecundities did not differ significantly between 1986 and 1987 (t-test, p > 0.25). The pooled mean of 687.1 ova g $^{-1}$ may be the best estimate of relative batch fecundity during the peak of the spawning season.

Relative batch fecundity declined significantly as ovary-free female weight increased in July 1986 (Regression Analysis, $p<0.01$ ) but did not differ significantly in July $1987(\mathrm{p}>0.20)$. The pooled 1986-1987 batch fecundity on female weight data also gave a significant regression $(p<0.01)$, suggesting that relative batch fecundity, although variable, declines slightly as female weight increases $(p<0.02)$. The linear regression for the pooled data is:

$$
\begin{gathered}
F=924.05-136.10 W_{i} \quad r^{2}=0.31, \mathrm{n}=20 \\
\text { SE of slope }=48.30
\end{gathered}
$$

where $F=$ relative batch fecundity (ova per batch per $g$ ovary-free female weight); and $W=$ ovary-free female weight $(g)$.

There were significant regression relationships between batch fecundity and female fork length ( $\mathrm{mm})$, female weight $(g)$, ovary-free female weight $(g)$ and ovary weight $(g)(p=0.0001$ to 0.0008$)$. Linear regression models accounted for a higher proportion of the variance and were judged better than power models in describing these relationships. These 4 relationships did not differ between the 2 years (ANCOVA, $p=0.17$ to 0.84 ). For pooled data from both years the regressions are:

Hydrated ova $=-1038.11+38.32$ (fork length); $\mathrm{r}^{2}=0.59$

Hydrated ova $=304.79+404.64$ (female $w t) ; r^{2}=0.71$ Hydrated ova $=393.67+421.84$ (ovary-free female $w t) ; r^{2}=0.63$

Hydrated ova $=244.16+3011.94$ (ovary wt) $; r^{2}=0.76$

The relationship between batch fecundity (i.e. hydrated ova) and ovary-free weight (Fig. 4) indicates that batch fecundity increased by 422 ova for each $1.0 \mathrm{~g}$ increase in ovary-free weight. An age-1 female of mean total weight $1.13 \mathrm{~g}$ (Newberger \& Houde unpubl.) would spawn 762 eggs per evening during the peak spawning season.

During the peak spawning period in 1986 and 1987 , age-1 anchovy in the 50 to $55 \mathrm{~mm}$ length range contributed most to total egg production in mid-Chesapeake Bay (Fig. 5). Newberger (1989) reported that in July 1986, age-1 bay anchovy ranged from 45 to $74 \mathrm{~mm}$ fork 


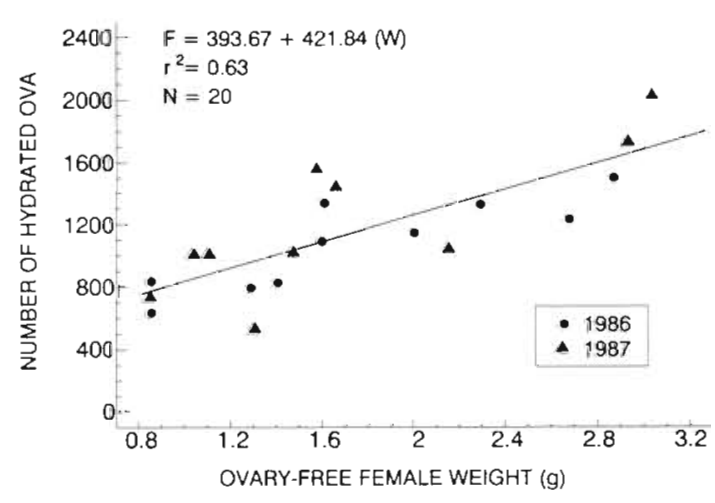

Fig. 4. Anchoa mitchilli. Relationship between batch fecundity (number of hydrated ova) and ovary-free female weight for 20 female bay anchovy examined from collections made on 30 July 1986 and 30 June 1987

length and age-2+ fish ranged from 71 to $87 \mathrm{~mm}$. In July 1987 , age- 1 fish ranged from 38 to $68 \mathrm{~mm}$ and age$2+$ fish were 68 to $84 \mathrm{~mm}$. Based on Newberger's (1989) size-frequency data and our equation, anchovy in the 50 to $55 \mathrm{~mm}$ length classes were estimated to contribute 57.3 and $52.6 \%$ to egg production in 1986 and 1987, respectively (Fig. 5). Age-1 females (10 to 14 mo posthatch) were estimated to have produced 99.6 and $92.8 \%$ of the eggs in July 1986 and July 1987. respectively. Essentially all remaining eggs were produced by age- 2 females.

\section{Hatch-date frequencies}

Most young-of-the-year anchovy collected by the trawl (i.e. recruits) were hatched in July 1986 and 1987.
A randomly-selected subset of 30 of the 210 otoliths used in this analysis indicated that 2 otolith readers had assigned different ages in days and, consequently, different hatch-dates (Wilcoxon's paired sample test, p < 0.05). Consequently, data were aggregated into weekly cohorts, which eliminated discrepancies between otolith readers (Wilcoxon's paired sample test, $\mathrm{p}>0.05$ ).

The weekly hatch-date frequency distributions of otolith-aged, trawl-collected anchovy in September and October indicated that hatch dates of recruits occurred and peaked earlier in 1987 than in 1986 (Fig. 6). The median hatch dates were 20 July in 1986 and 9 July in 1987. The hatch-date frequency distributions differed significantly between 1986 and 1987 (Kolmogorov-Smirnov test, $\mathrm{p}<0.05$ ). In 1987, hatching of recruits was estimated to have occurred initially in the first week of June and continued until the third week of August, with peak hatching centered around 2 July. In 1986, hatching was not evident until the second week in June and was not observed after the second week in August.

Peak hatchings in 1986 were observed from 16 July to 30 July (Fig. 6). Cumulative estimates indicated that $>80 \%$ of the observed recruits had hatched by 30 July 1986 and by 16 July 1987. More than $95 \%$ of the sampled recruits had hatched by 6 August 1986 and 30 July 1987

\section{Young-of-the-year growth rates}

The size-at-age distributions of young-of-the-year bay anchovy collected from August to October (Table 1), and included in the growth-rate analysis, are
Fig. 5. Anchoa mitchilli. Relative contribution to total egg production by female bay anchovy in $1 \mathrm{~mm}$ length-classes in (a) July 1986 and (b) July 1987. Bars: percent; ( ) cumulative percent contribution
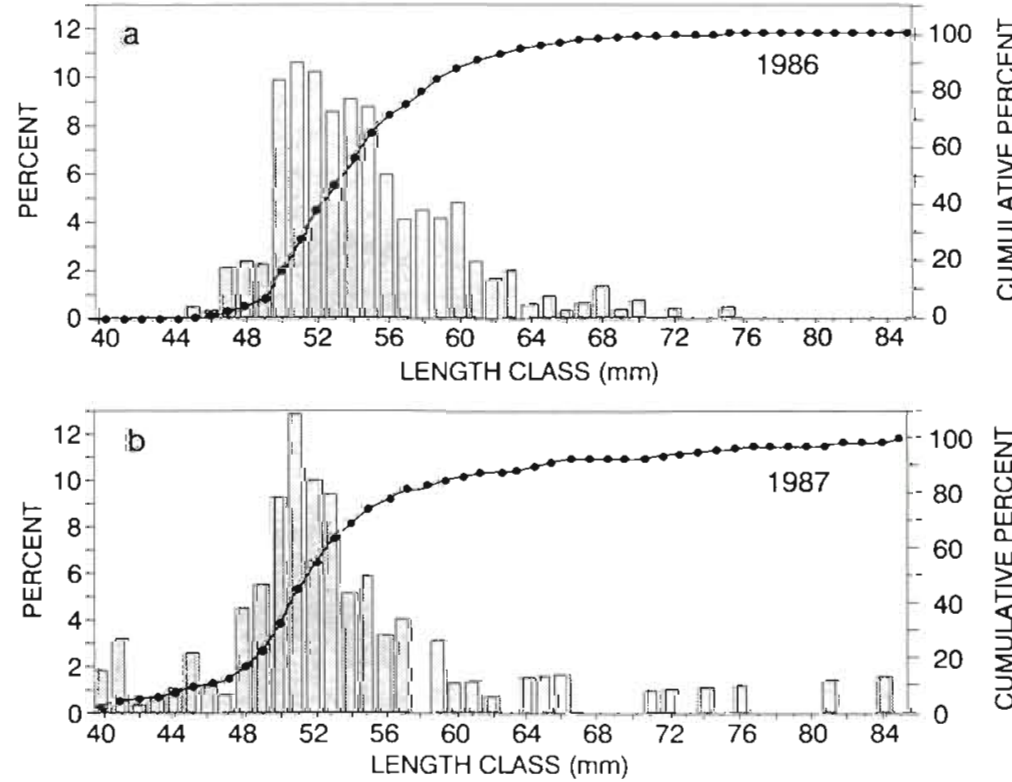


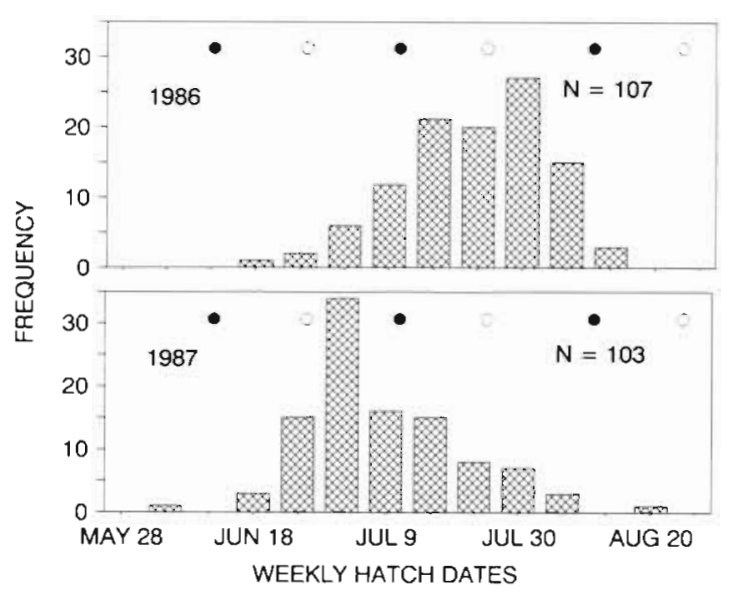

Fig. 6. Anchoa mitchilli. Weekly hatch-date frequency distributions of bay anchovy in 1986 and 1987. Moon phases are indicated: (•) new moon; (o) full moon

illustrated in Fig. 7. Mean individual growth rates were identical in 1986 and 1987 at $0.47 \mathrm{~mm} \mathrm{~d}^{-1}$ (Table 1). Growth-rate frequency distributions of individuals in 1986 and 1987 (Fig. 8) were similar. In each year most growth rates ranged from 0.44 to $0.50 \mathrm{~mm} \mathrm{~d}^{-1}$, although the range of estimated growth rates was broader in 1986 (Table 1, Fig. 8).

\section{DISCUSSION}

Male and female bay anchovy in mid-Chesapeake Bay matured at ca 40 to $45 \mathrm{~mm}$ fork length in 1986 and 1987. These lengths correspond to an average first maturity age of ca 10 mo posthatch (Newberger 1989).

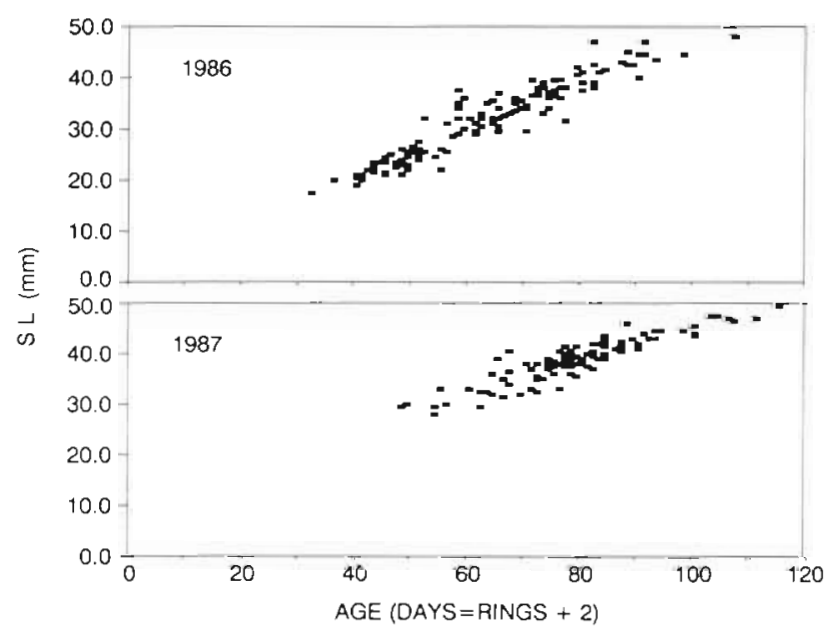

Fig. 7. Anchoa mitchilli. Scatter plots of standard lengths (SL) and estimated ages (otolith increments +2 ) of young-of-theyear bay anchovy collected from August to October in midChesapeake Bay, 1986 and 1987

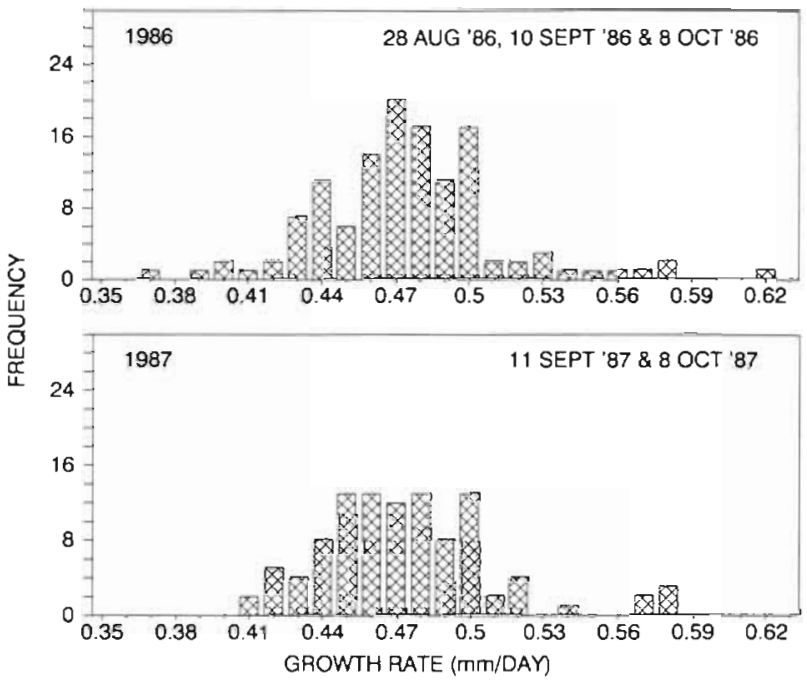

Fig. 8. Anchoa mitchilli. Growth-rate frequencies of young-ofthe-year bay anchovy derived from otolith-increment age estimates in 1986 and 1987

We had hypothesized that some bay anchovy mature and spawn at age-0+, when only 3 mo posthatch, but no mature age-0+ individuals were observed in late summer of 1986 and 1987 . However, it is possible that some anchovy do mature during their first summer in mid-Chesapeake Bay as Hildebrand \& Schroeder (1928) had suggested. Luo \& Musick (in press) observed some female bay anchovy from the lower Chesapeake Bay that were mature at age-0+ and $<40 \mathrm{~mm}$ fork length in late summer 1988. Stevenson (1958) found 35 to $40 \mathrm{~mm}$ standard length bay anchovy that were mature in the Delaware Bay (ca 39.6 to 45.4 $\mathrm{mm}$ fork length) (PSEG 1984). He suggested that they were young-of-the-year although he did not age the fish. Some bay anchovy collected in the Laguna de Terminos in the Gulf of Mexico were sexually mature at $37.5 \mathrm{~mm}$ standard length (SL) (Flores-Coto et al. 1988). Size and age at maturity differ widely among engraulid species. For example, northern anchovy Engraulis mordax mature at 104 to $197 \mathrm{~mm} \mathrm{SL}$ and age 2 (LaRoche \& Richardson 1980), while the small, short-lived, tropical nehu Encrasicholina purpurea may mature at $40 \mathrm{~mm}$ SL when less than 6 mo of age (Clarke 1987).

In 1986 and 1987 most egg production in midChesapeake Bay was by age-1 (10 to 14 mo posthatch) bay anchovy. Spawning by older fish accounted for only 0.4 and $7.2 \%$ of July egg production in 1986 and 1987, respectively. Annual mortality rate of bay anchovy is high, and few fish survive to ages 2 and 3 (Newberger \& Houde unpubl.). Thus, a recruitment failure for a single year would have a major impact on egg production in the following year.

The spawning season of bay anchovy in the Chesapeake Bay extends from May to September 
(Dovel 1971, Olney 1983, Dalton 1987, Luo \& Musick in press). The principal spawning dates in midChesapeake Bay in 1986 and 1987 appeared to extend from mid-May until mid-August and the major spawning activity was in July. Dalton (1987) found that bay anchovy egg abundances in mid-Chesapeake Bay generally peaked in mid to late July during a 6 yr ichthyoplankton study in the 1970s. The spawning seasons for bay anchovy in Delaware Bay, Barnegat Bay, and Great South Bay also occur primarily from May to August with peak spawning in July (PSEG 1984, Vouglitois et al. 1987, Monteleone 1988). In Biscayne Bay, Florida, near the southern part of its range, bay anchovy may spawn throughout the year (Houde \& Lovdal 1984).

Bay anchovy, like most engraulids, spawns in the evening. For example, the northern anchovy spawns between 20:00 and 04:00 h (Hunter \& Goldberg 1980) and the Hawaiian anchovy (nehu) spawns only in a $1 \mathrm{~h}$ period after sunset (Clarke 1987, 1989). Female bay anchovy with hydrated ova in mid-Chesapeake Bay were observed from 17:57 to 00:33 h. Spawning near Beaufort, North Carolina (Hildebrand \& Cable 1930) and in Peconic Bay, New York (Ferraro 1980) occurred between 18:00 and 21:00 h. Spawning in the York River took place within a $1.5 \mathrm{~h}$ time period beginning at 20:00 h in June but at 23:30 h in September (Luo \& Musick in press).

Clupeiform fishes such as anchovies, sardines and sprats are serial (batch) spawners (Alheit 1989). We found that from 67 to $100 \%$ of female bay anchovy collected during the evening in June and July 1987 were about to spawn (i.e. had hydrated ova). After 10 June 1987 and throughout July, $100 \%$ of the females examined during the evening had hydrated ova, indicating that virtually all females spawned nightly in midChesapeake Bay during the peak spawning season. If females with hydrated ova were more vulnerable to trawls than females with non-hydrated oocytes, as observed for northern anchovy (Hunter \& Macewicz 1985), the percentage of daily spawners could have been overestimated. However, female bay anchovy with unhydrated oocytes were rarely collected between 18:00 and 01:00 h (Table 3), while unhydrated females were caught regularly in daytime and after 01:00 h. The fact that $100 \%$ of females collected from 17:57 to 23:00 h had hydrated ova from mid-June through July 1987 is strong evidence that nearly all females spawned daily during the peak spawning season.

Hydration in bay anchovy females from the York River ranged from $25 \%$ in early June to $81 \%$ in midJuly 1988 (Luo \& Musick in press), indicating that spawning interval there was every $4 \mathrm{~d}$ in early June and every $1.3 \mathrm{~d}$, on average, during July. Although our data were insufficient to calculate the average number of spawnings per female, it appears that each female must spawn a minimum of 50 times in the 1 June to 15 August period based on our hydrated condition and gonosomatic index results. Luo \& Musick (in press) calculated that the average annual number of spawnings per female in the York River was 55. Our results and those of Luo \& Musick (in press) contradict Stevenson (1958) who, based on oocyte-size distributions, believed that Delaware Bay anchovy spawned only once in a spawning season. The percentage of other engraulid species females that spawn each day generally is lower and more variable than bay anchovy. Reported daily spawning percentages are: northern anchovy Engraulis mordax, 9.4 to $16.0 \%$ (Hunter \& Goldberg 1980, Bindman 1986); Peru anchoveta E. ringens, $16 \%$ (Alheit et al, 1984); South African anchovy E. capensis, 9.5 to $18.6 \%$ (Armstrong et al. 1988); European anchovy E. encrasicholus, ca 30 to $35 \%$ ( Santiago \& Sanz 1989, Sanz et al. 1989); and nehu Encrasicholina purpurea $50 \%$ (Clarke 1987).

Relative batch fecundities did not differ significantly between July 1986 and July 1987. Our July estimates (643 in 1986 and 731 in 1987) are similar to or slightly lower than the July 1988 values reported in the York River (743) for fish of similar size (Luo \& Musick in press). From a regression equation, we estimated that a $55 \mathrm{~mm}$ FL anchovy would produce 1069 hydrated ova per batch while Luo \& Musick (in press) predicted batch fecundities ranging from 442 (June) to 999 (July). Similarly, a $1.0 \mathrm{~g}$ ovary-free-weight anchovy would produce 816 ova per batch based upon our regression but 341 (June) to 785 (August) based upon Luo \& Musick's (in press) regressions. Relative batch fecundity for Anchoa mitchilli collected in the Laguna de Terminos was 824 ova g $^{-1}$ (Flores-Coto et al. 1988).

Reported relative batch fecundities of other engraulids range from 368 to 885 ova $^{-1}$. The relative fecundities of Anchoa naso in Ecuador (Joseph 1963) and Cetengraulis mysticetus in the Gulf of Panama (Peterson 1961) were 885 and 863, respectively. These values are higher than that of bay anchovy. Relative fecundity of the northern anchovy ranged from 421 for a central subpopulation off California (Hunter \& Macewicz 1985) to 826 for a northern subpopulation off Oregon and Washington (LaRoche \& Richardson 1980). Relative batch fecundity of Peru anchoveta ranged from 466 to 637 (Alheit \& Alegre 1986), while that of the Hawaiian anchovy (nehu) ranged from 368 in winter to 566 in summer (Clarke 1987), values apparently lower than those for bay anchovy

The earlier median and modal hatch dates in 1987 may have been attributable to earlier spawning induced by earlier warming and sustained higher temperatures that year (Houde et al. 1989). Alternatively, larval survival could have differed between 1986 and 1987, producing the different hatch-date distributions 
of survivors. Because there were no egg or larvae surveys in 1986 and 1987, the temporal variability in egg production is unknown. Mean Bay temperatures during July $1986\left(27.2^{\circ} \mathrm{C}\right)$ and July 1987 (27.8 $\left.{ }^{\circ} \mathrm{C}\right)$ were warmer than the long-term July mean temperature $\left(26.7^{\circ} \mathrm{C}\right.$ ) (Kelly 1988), but effects of warmer than average temperatures on the timing and extent of egg production are not known.

Growth rates of young-of-the-year bay anchovy averaged $0.47 \mathrm{~mm} \mathrm{~d}^{-1}$ and were the same in 1986 and 1987. The 5 mean growth rates that we calculated (Table 1) were similar, indicating that the method gave consistent results. The rates also were similar to growth rates of larvae reported by Cowan \& Houcle (1990) in mesocosm experiments in the Chesapeake Bay, and by Leak \& Houde (1987) in Biscayne Bay, Florida, and were within the range $\left(0.24\right.$ to $\left.1.11 \mathrm{~mm} \mathrm{~d}^{-1}\right)$ reported by Fives et al. (1986) in the Newport River, North Carolina. Newberger \& Houde (unpubl.) estimated the mean young-of-the-year growth rate in mid-Chesapeake Bay during $1986-1987$ to be $0.41 \mathrm{~mm} \mathrm{~d}^{-1}$. Their estimate, derived from a von Bertalanffy model, is similar to our estimate of $0.47 \mathrm{~mm} \mathrm{~d}^{-1}$ for anchovy collected during the same time of year and with identical gear.

We hypothesized that moon phase might have influenced spawning activity of bay anchovy and, consequently, the observed hatch-date frequency distributions. In French grunt Haemulon flavolineatum (McFarland et al. 1985) and Caribbean damselfish Stegastes partitus (Robertson et al. 1988), settlement onto reefs was demonstrated to be keyed to biweekly moon-phase events associated with spawning peaks. There was no apparent relationship between new or full-moon phases and hatch-date frequencies of surviving juvenile bay anchovy. It is likely that anchovy spawning is keyed more to temperature and seasonal light cycles than to lunar periodicity. In temperate fish species, changing photoperiod, temperature and the interaction between these 2 environmental factors are the primary factors affecting the timing of gonadal maturation and spawning (Schwassmann 1971). It remains possible that the observed hatch-date frequencies of bay anchovy differed from the pattern of eggproduction if larval survival was variable during the reproductive season.

Acknowledgements. We thank T. Newberger, E. Chesney, K. Kavanaugh, E. Sanders and R. Nyman for assistance in the field and laboratory. J. Luo and J. H. Cowan, Jr reviewed drafts of the manuscript. F. Younger provided illustrating assistance and L. Fernandez prepared the manuscript. Research was sponsored by NOAA Office of Sea Grant, Department of Commerce, under Grant NA86AA-D-SG006 to the University of Maryland Sea Grant College. Contribution No. 2218 of the University of Maryland System. Center for Environmental and Estuarine Studies.

\section{LITERATURE CITED}

Alheit, J. (1989). Comparative spawning biology of anchovies, sardines and sprats. Rapp. P.-v. Réun. Cons. Int. Explor. Mer 191. 7-14

Alheit, J., Alarcon, V. H., Macewicz, B. (1984). Spawning frequency and sex ratio in the Peruvian anchovy, Engraulis ringens. Calif. Coop. Oceanic Fish. Invest. Rep. 24: 43-52

Alheit, J., Alegre, B. (1986). Fecundity of Peruvian anchovy, Engraulis ringens. Comm. Meet. int. Coun. Explor. Sea C.M.-ICES/H: 60

Armstrong, M., Shelton, P., Hampton, I., Jolly, G., Melo, Y. (1988). Egg production estimates of anchovy biomass in the southern Benguela system. Calif. Coop. Oceanic Fish. Invest. Rep. 29: 137-157

Bagenal, $T$ (1978). Methods for assessment of fish production in fresh waters. IBP Handbook No. 3, 3rd edn. Blackwell Scientific Publications, Oxford

Baird, D., Ulanowicz, R. E. (1989). The seasonal dynamics of the Chesapeake Bay Ecosystem. Ecol. Monogr 59 (4): 329-362

Bindman, A. G. (1986). The 1985 spawning biomass of the northern anchovy. Calif. Coop. Oceanic Fish. Invest. Rep. 27: $16-24$

Clarke, T. A. (1987). Fecundity and spawning frequency of the Hawaiian anchovy or nehu, Encrasicholina purpurea. Fish. Bull. U.S. 85 (1): 127-137

Clarke, T A. (1989). Seasonal differences in spawning, egg size, and early development time of the Hawaiian anchovy or nehu, Encrasicholina purpurea. Fish. Bull. U.S. 87: $593-600$

Cowan, J. H. Jr, Houde, E. D. (1990). Growth, growth rate variability, and survival of bay anchovy (Anchoa mitchilli) larvae in mesocosm enclosures. Mar Ecol. Prog. Ser 68: $47-57$

Dalton, P. D. (1987). Ecology of bay anchovy (Anchoa mitchilli) eggs and larvae in the Mid-Chesapeake Bay. Masters's thesis, Univ. Maryland, College Park

Dovel, W. L. (1971). Fish eggs and larvae of the upper Chesapeake Bay. Nat. Res. Inst., Univ, Maryland Spec. Rep. No. 4

Ferraro, S. P. (1980). Pelagic fish eggs and larvae of the Peconic Bays, New York: 1972-1974. Ph.D. thesis, State University of New York, Stony Brook

Fives, J. M., Warlen, S. M., Hoss, D. E. (1986). Aging and growth of larval bay anchovy, Anchoa mitchilli, from the Newport River estuary, North Carolina. Estuaries 9: $362-367$

Flores-Coto, C. F., Ocana-Luna, A., Luna-Calvo, A., ZaralaGarcía, F. (1988). Abundancia de algunas especies de anchoas en la Laguna de Términos (México), estimada a través de la captura de huevos. An. Inst. Cienc. del Mar y Limnol. Univ. Nat. Autón. México 15: 125-134

Hildebrand, S. F., Cable, L. E. (1930). Development and life history of 14 teleostean fishes at Beaufort, North Carolina. Fish. Buil. U S. 46 : $383-488$

Hildebrand, S. F., Schroeder, W. C. (1928). Fishes of Chesapeake Bay. Fish. Bull. U.S. 43: 1-388

Horwitz, R. J. (1987). Fish. In: Heck, K. L. (ed.) Ecological studies in the middle reach of Chesapeake Bay. Lecture Notes on Coastal and Estuarine Studıes 23. Springer-Verlag, Berlin, p. 167-224

Houde, E. D. Lovdal, J. A. (1984). Seasonality of occurrence. foods and tood preferences of ichthyoplankton in Biscayne Bay, Florida. Estuar coast. Shelf Sci. 18: 403-419

Houde, E. D., Chesney, E. J. Jr, Newberger, T A., Vazquez, A V., Zastrow, C. E., Morin, L. G., Harvey, H. R., Gooch, J. W 
(1989). Population biology of bay anchovy in midChesapeake Bay. Center for Environmental and Estuarine Studies, Chesapeake Biological Laboratory. Final Report to Maryland Sea Grant. Ref. No. [UMCEES]-CBL 89-141

Hunter, J. R., Goldberg, S. R. (1980). Spawning incidence and batch fecundity in northern anchovy, Engraulis mordax. Fish. Bull. U.S. 77: 641-652

Hunter, J. R., Lo, N. C. H., Leong, R. J. H. (1985). Batch fecundity in multiple spawning fishes. In: Lasker, R. (ed.) An egg production method for estimating spawning biomass of pelagic fish: application to the northern anchovy, Engraulis mordax. NOAA Tech. Rep. NMFS 36, p. 67-77

Hunter, J. R., Macewicz, B. J. (1985). Measurement of spawning frequency in multiple spawning fishes. In: Lasker, R. (ed.) An egg production method for estimating spawning biomass of pelagic fish: application to the northern anchovy, Engraulis mordax. NOAA Tech. Rep. NMFS 36, p. $79-94$

Joseph, J. (1963). Contribution to the biology of the engraulid Anchoa naso (Gilbert and Pierson 1898) from Ecuadorian waters. Inter-Am. Trop. Tuna Comm. Bull. 8: 1-30

Kelly, K. L. (ed.) (1988). Chesapeake Bay marine environmental assessment, 1985 annual summary. Chesapeake Res. Consortium Publ. No. 128, 51 p.

Kuntz, A. (1914). The embryology and larval development of Bairdiella chrysura and Anchovia mitchilli. Bull. Bur. Fish., Wash. 33: 1-19

LaRoche, J. L., Richardson, S. L. (1980). Reproduction of northern anchovy, Engraulis mordax, off Oregon and Washington. Fish. Bull. U.S. 78: 603-618

Leak, J. C., Houde, E. D. (1987). Cohort growth and survival of bay anchovy Anchoa mitchilli larvae in Biscayne Bay, Florida. Mar. Ecol. Prog. Ser. 37: 109-122

Luo, J., Musick, J. A. (in press). Reproductive biology of the bay anchovy in Chesapeake Bay. Trans. Am. Fish. Soc.

McFarland, W. N., Brothers, E. B., Ogden, J. C., Shulman, M. J., Bermingham, E. L., Kotchian-Prentiss, N. M. (1985). Recruitment patterns in young French grunts, Haemulon

This article was submitted to the editor flavolineatum (Family Haemulidae), at St. Croix, Virgin Islands. Fish. Bull. U.S. 83: 413-426

Monteleone, D. M. (1988). Trophic interactions of ichthyoplankton in Great South Bay, New York. Ph. D. thesis, State Univ. of New York, Stony Brook

Newberger, T A. (1989). Relative abundance, age, growth and mortality of bay anchovy in the Mid-Chesapeake Bay. Master's thesis, University of Maryland, College Park

Olney, J. E. (1983). Eggs and early larvae of the bay anchovy, Anchoa mitchilli, and the weakfish, Cynoscion regalis, in lower Chesapeake Bay with notes on associated ichthyoplankton. Estuaries 6 (1): 20-35

Public Service Electric and Gas Company (1984). Bay anchovy (Anchoa mitchilli): a synthesis of information of natural history, with reference to occurrence in the Delaware River and estuary and involvement with the Salem Generating Station. Salem Generating Station 316 (b). Demonstration. Appendix XII, Bay Anchovy (Anchoa mitchilli)

Robertson, D. R., Green, D. G., Victor, B. C. (1988). Temporal coupling of production and recruitment of larvae of a Caribbean reef fish. Ecology 69 (2): 370-381

Santiago, J., Sanz, A. (1989). Daily fecundity of the Bay of Biscay anchovy population in 1988. Comm. Meet. int. Coun. Explor. Sea C.M.-ICES/H: 33

Sanz, A., Motos, L., Uriarte, A. (1989). Daily fecundity of the Bay of Biscay anchovy population in 1987. Comm. Meet. int. Coun. Explor Sea C.M.-ICES/H: 42

Schwassmann, H. O. (1971). Biological rhythms. In: Hoar, W. S., Randall, D. J. (eds.) Fish physiology, Vol. VI, Environmental relations and behavior. Academic Press, New York, p. $371-428$

Stevenson, R. A. Jr (1958). The biology of the anchovies Anchoa mitchilli Cuvier and Valenciennes 1848 and Anchoa hepsetus Linnaeus 1758 in Delaware Bay. Master's thesis, University of Delaware, Newark

Vouglitois, J. J., Able, K. W., Kurtz, R. J., Tighe, K. A. (1987). Life history and population dynamics of the bay anchovy in New Jersey. Trans. Am. Fish. Soc. 116: 141-153

Manuscript first received: October 23, 1990

Revised version accepted: April 18, 1991 